\title{
A new view from La Cotte de St Brelade, Jersey
}

\author{
Beccy Scott ${ }^{1}$, Martin Bates ${ }^{2}$, Richard Bates ${ }^{3}$, Chantal Conneller ${ }^{4}$, \\ Matt Pope ${ }^{5}$, Andrew Shaw ${ }^{6} \&$ Geoff Smith $^{7}$
}

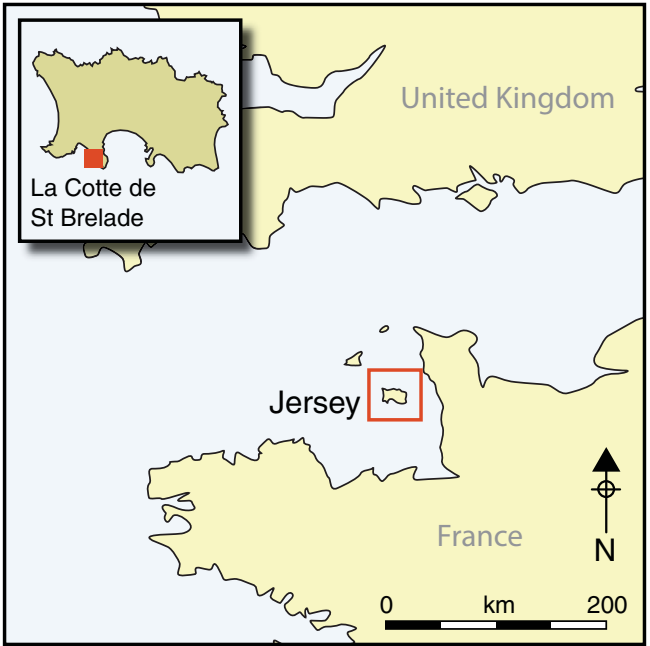

wind-blown loess.
Did Neanderthal hunters drive mammoth herds over cliffs in mass kills? Excavations at La Cotte de St Brelade in the 1960s and 1970s uncovered heaps of mammoth bones, interpreted as evidence of intentional hunting drives. New study of this Middle Palaeolithic coastal site, however, indicates a very different landscape to the featureless coastal plain that was previously envisaged. Reconsideration of the bone heaps themselves further undermines the 'mass kill' hypothesis, suggesting that these were simply the final accumulations of bone at the site, undisturbed and preserved in situ when the return to a cold climate blanketed them in

Keywords: Channel Islands, Jersey, Middle Palaeolithic, Neanderthal, mass kill, mammoth hunting, bathymetric survey

\section{Introduction: regarding La Cotte}

Jersey is the largest of the Channel Islands, comprising outcrops of igneous, sedimentary and metamorphic geologies which rise $120 \mathrm{~m}$ at the north of the island and dip to the south

1 Department of Prehistory and Europe, The British Museum, Franks House, 28-55 Orsman Road, London N1 5QJ, UK (Email: rscott@thebritishmuseum.ac.uk)

2 Department of Archaeology, University of Wales Trinity Saint David, Lampeter, Ceredigion SA48 7ED, UK (Email:m.bates@tsd.ac.uk)

3 Department of Geography, University of St Andrews, North Street, St Andrews KY16 9AL, UK (Email: crb@st-andrews.ac.uk)

4 Department of Archaeology, University of Manchester, Oxford Road, Manchester M13 9PL, UK (Email: chantal.conneller@manchester.ac.uk)

5 Institute of Archaeology, University College London, 31-34 Gordon Square, London WC1H OPY, UK (Email: m.pope@ucl.ac.uk)

6 Centre for the Archaeology of Human Origins, Department of Archaeology, University of Southampton, Highfield, Southampton SO17 1BF, UK

7 Monrepos Archaeological Research Centre and Museum for Human Behavioural Evolution (RGZM), Schloss Monrepos 56567, Neuwied, Germany (Email: smith@rgzm.de) 


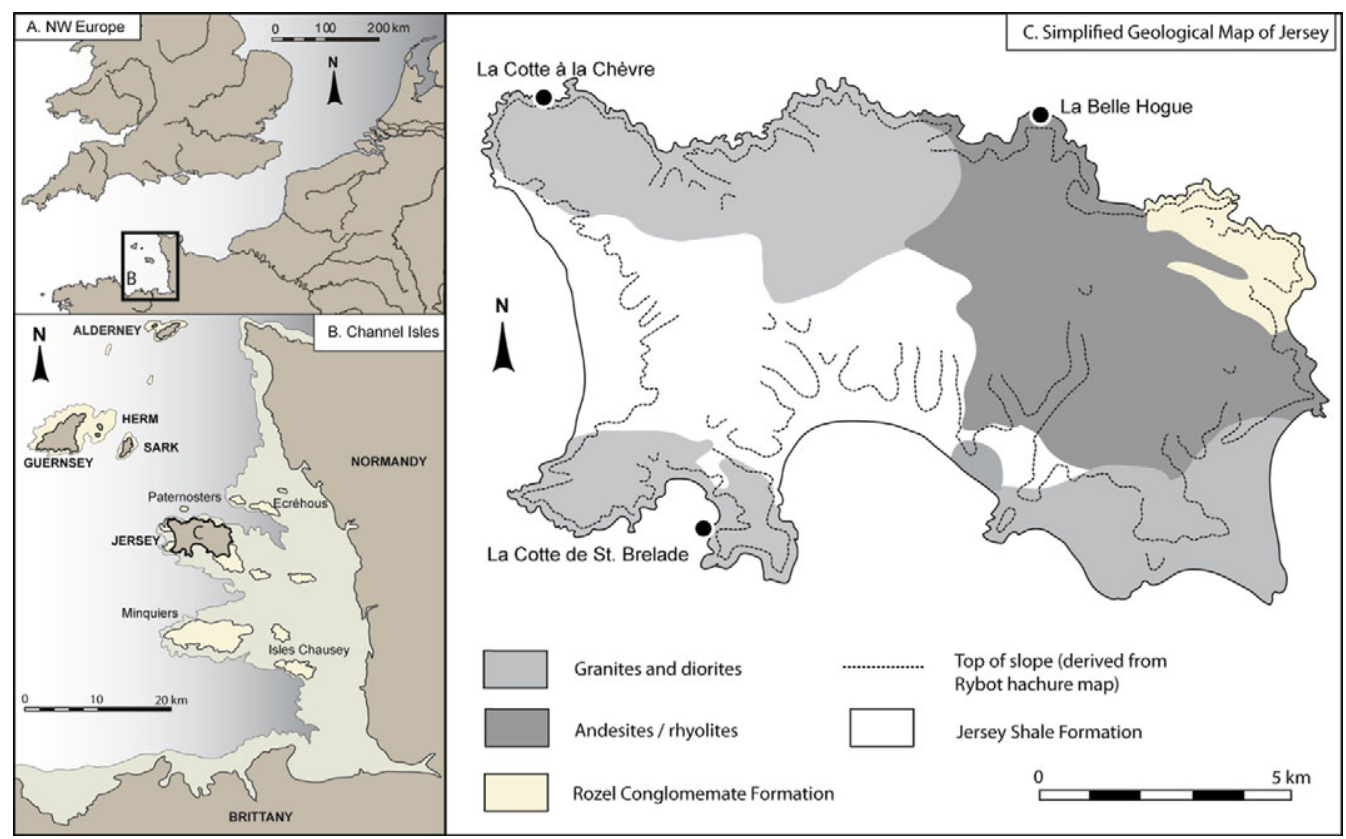

Figure 1. A) Position of the Channel Islands within north-western Europe; B) position of Jersey in relation to the other Channel Islands and the northern French coast; C) simplified geological map of Jersey, showing the position of the main sites mentioned in the text. Based upon an image supplied by John Renouf.

into a series of embayments (Figure 1). The topographic and landscape setting of the island of Jersey would have altered profoundly according to climate and associated sea level change throughout the Pleistocene. During cool-cold and low sea level events, Jersey would have been joined to northern France, isolated between broadly south-east to north-west trending rivers running between Jersey and the modern Cotentin Peninsula (to the north-west) and the Minquiers to the south (see Figure 1). Jersey would have been widely visible across the exposed landscapes of the Channel river plain as an upstanding 'terrestrial island' or plateau, especially from the north, becoming progressively isolated as the climate warmed and sea level rose; sea level heights some $10 \mathrm{~m}$ below modern levels would have served to isolate Jersey as an island.

Jersey provides many contexts for the preservation of Pleistocene sediments. These include head and loess deposits, at least four raised beach sequences, head-filled coastal fissures, and sea caves. Two such caves are La Belle Hogue, which produced an important Marine Isotope Stage (MIS) 5e dwarf red deer fauna, and La Cotte à la Chèvre, which contained Middle Palaeolithic archaeology (Zeuner 1946; Callow 1986c). La Cotte de St Brelade is, however, the foremost of Jersey's Pleistocene locales and offers an archaeological record of Continental significance.

La Cotte de St Brelade has played a significant role in the study of Neanderthal behavioural capacity and organisational abilities. For the past quarter-century the artefact and faunal assemblages from the site have contributed to discussions of Neanderthal subsistence and hunting strategies during the late Middle Pleistocene (Callow \& Cornford 1986).

(C) Antiquity Publications Ltd. 
However, despite the site offering the most detailed and extensive record of Neanderthal occupation in Northern Europe (spanning c. 238-40 k BP), one impression has dominated the archaeological consciousness: that the deep ravines at La Cotte de St Brelade provided a location for game drives by Neanderthal hunters.

This compelling impression is derived from Kate Scott's pioneering faunal analysis of two distinctive bone heaps (early MIS 6) which formed part of the deep stratigraphic sequence at La Cotte (Scott 1980, 1986b). Scott concluded that the composition and arrangement of the bone heaps was most consistent with Neanderthal hunters driving mammoth herds over the headland into the deep granite ravines. The involvement of Neanderthals in premeditated and organised predation challenged assumptions concerning their cognitive capabilities as hunters (Binford 1985; Chase 1986; Stiner 1994). La Cotte de St Brelade therefore entered the canon of key Middle Palaeolithic localities which offered in the last decades of the twentieth century a new perspective on Neanderthal populations.

\section{Reconsidering La Cotte}

The excavated material from La Cotte has remained largely unstudied for the last 25 years. Although frequently referenced, the game-drive hypothesis has never been readdressed. New sites and studies have reinforced the complexity of Neanderthal hunting, confirming highly organised, logistical and socially cooperative behaviours. Yet, beyond reference to the hypothesised game drives and consequent reinforcement of the phenomenon as fact, the concept itself has escaped scrutiny. Concurrently, research on Middle Palaeolithic occupation patterns and landscape use in Northern Europe has developed a deeper understanding of how Neanderthal groups organised themselves in space and time, showing clear evidence for landscape preference, spatially extended lithic chaînes opératoires (Geneste 1989), openair occupation sites incorporating living spaces and/or structures (Demay et al. 2012), and task-specific extraction and butchery sites (Boismier et al. 2012). Understanding of more permanent occupation patterns in Northern Europe has been impaired by a paucity of deeply stratified sites containing unambiguously 'domestic' material. La Cotte has the potential to address such issues, but has been largely overlooked, despite its long, wellstratified sedimentary sequence and exceptional quantity of provenanced finds, totalling 200000 artefacts.

Reconsidering the potential of both the site and archive of La Cotte was a core aim of the Quaternary Archaeology and Environments of Jersey project (QAEJ; Pope et al. 2012). A programme of site investigation, archive assessment and reanalysis was initiated, effectively 'taking the pulse' of La Cotte-identifying aspects that required attention, delimiting the extent, scope and importance of unexcavated portions of the site, and initiating complete reorganisation of the site archive. This work, reported below, has allowed us to refocus on the site. In addition, an important new view of La Cotte de St Brelade was gained by understanding its landscape setting in detail, both on the terrestrial headland and through exploration of its now submerged environs through bathymetric survey.

(C) Antiquity Publications Ltd. 


\section{View to a kill: topography of the game drive route}

One particular view of La Cotte dominates the archaeological consciousness. The site is invariably photographed from within the fissure itself, or from the beach at low tide (Figure 2), visually reinforcing the game drive hypothesis by emphasising the precipitate drop into the fissure system. This view of La Cotte sees the dissected modern coastline contrasting heavily with the flat plateau above the site and that submerged beneath the sea. In effect, modern sea level has a tabula rasa effect, fooling the eye into assuming that a flat horizon and landscape has always lain beyond the modern coastline.

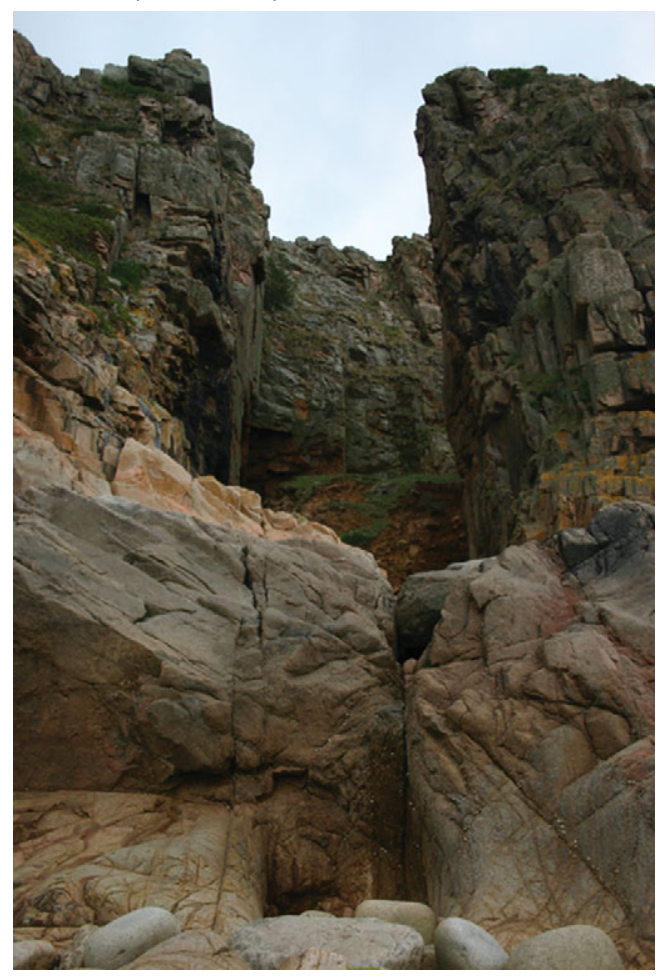

Figure 2. View facing east, looking up into the western ravine of the fissure system of La Cotte from the beach.
Approaching the site from above offers a different view (Figure 3); the ravines are part of a wider system dissecting the headland. La Cotte Point is indeed isolated, protruding north-west into St Brelade's Bay, connected to Portelet Common by a narrow neck of land and superficially forming a topographic projection of the wide plateau suitable for game drives. However, crossing this projection actually entails crossing complex, rocky and rugged topography, involving a significant dip and near vertical climb out over the last granite outcrop (Figures $4 \& 5$ ). This depression aligns with joints mapped elsewhere and may represent an infilled fissure. Modern African elephants have been shown actively to avoid rugged ground, and especially steep topography, because of the energy costs incurred by their body weight (Wall et al. 2006); this pattern is especially pronounced for females with young (de Knegt et al. 2010).

The topography of the headland would present a significant barrier to mammoths (Figure 5). Successfully driving animals over the cliff would first require that they be present upon an elevated, rocky plateau; modern African elephants avoid and 'stream around' isolated landforms (Wall et al. 2006). Jersey could have represented just such an isolated plateau during low sea level events. If such a herd was present, driving them over the cliff would then require forcing them over these natural barriers and up onto a fairly restricted space on the headland. Rather than being a flat, narrowing plateau leading straight to a precipitate drop, however, this landscape would divide a herd and actively direct them away from the supposed death trap. That does not preclude the possibility that cliffs around the headland were used in this way, but this would involve the transport of large carcass elements into the cave to form the bone heaps, a scenario at odds with Scott's original argument for the game drive based on skeletal completeness.

(C) Antiquity Publications Ltd. 


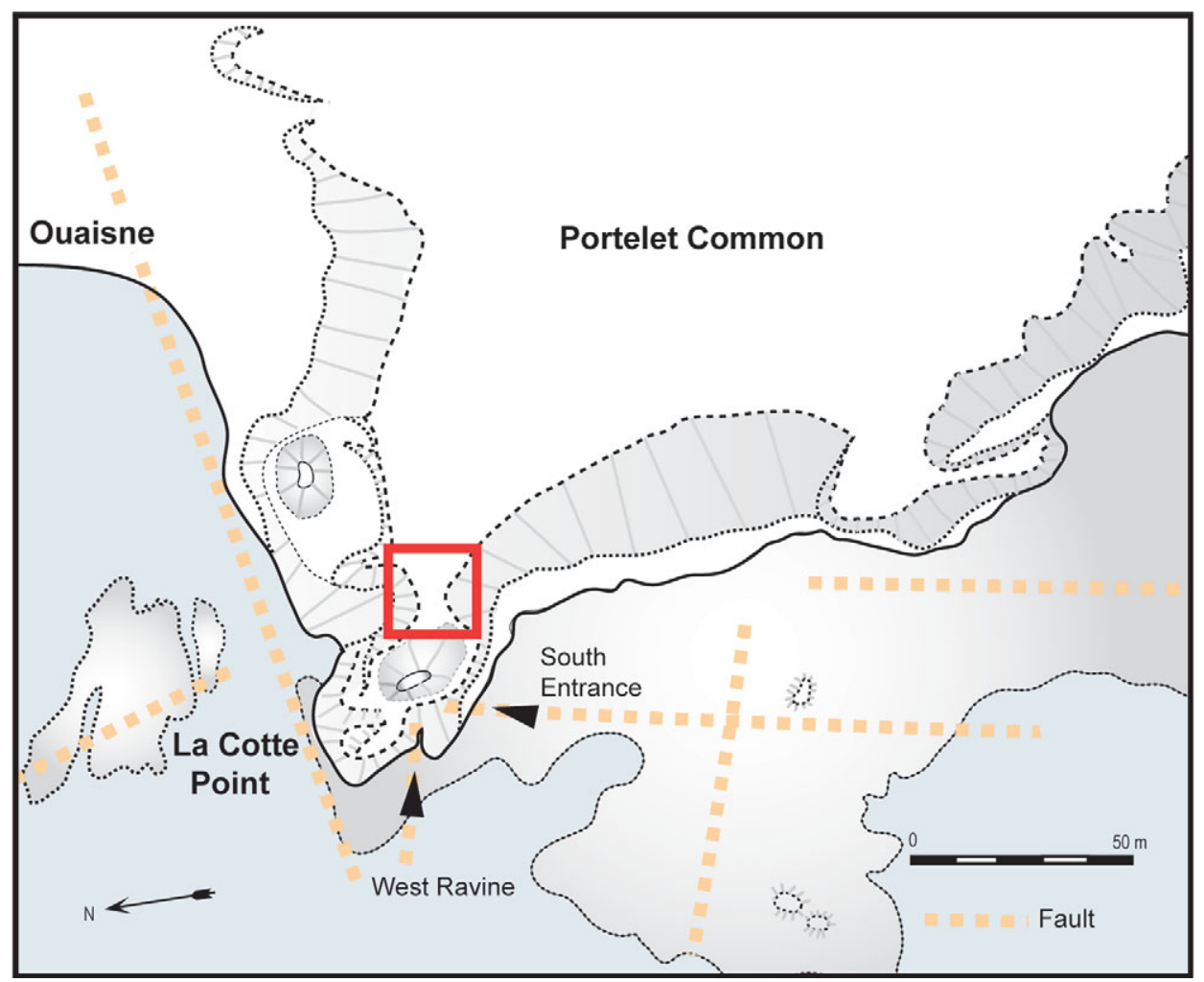

Figure 3. Modern topography of La Cotte Point as projection from Portelet Common. Note the constriction (boxed in red) before the steep climb to reach ground above the fissure system, in line with the fault mapped to the north. This would have formed a significant barrier (modified from Callow \& Cornford 1986: fig. 4.5).

\section{Commanding ground: offshore bathymetric survey and the landscape setting of La Cotte}

A more compelling picture of La Cotte within its landscape came not from the site but from a seabed survey conducted in the summer of 2011. The results provided us with the fundamental shift in perspective which has guided the overall new view of La Cotte de St Brelade presented here. The precise configuration of the local landscape would have varied immensely with shifts in sea level. Mapping the seabed landscapes surrounding La Cotte has allowed us to understand the controlling structure of the local offshore topography, thus relocating La Cotte within the low sea level landscape it would have occupied when the bone heaps were deposited. Sonar systems using bathymetric sidescan sonar from two survey vessels were deployed within and beyond St Brelade's Bay. The survey obtained data from the deeper offshore waters through to the rocky intertidal zone, with overlap between the two datasets. Survey of the intertidal rock platform in front of La Cotte using land-based theodolite measurements provided another area of overlap, ensuring integration of offshore and onshore data, and allowing development of a seamless model from both marine and terrestrial sectors (an approach adopted by Bates et al. 2012). 

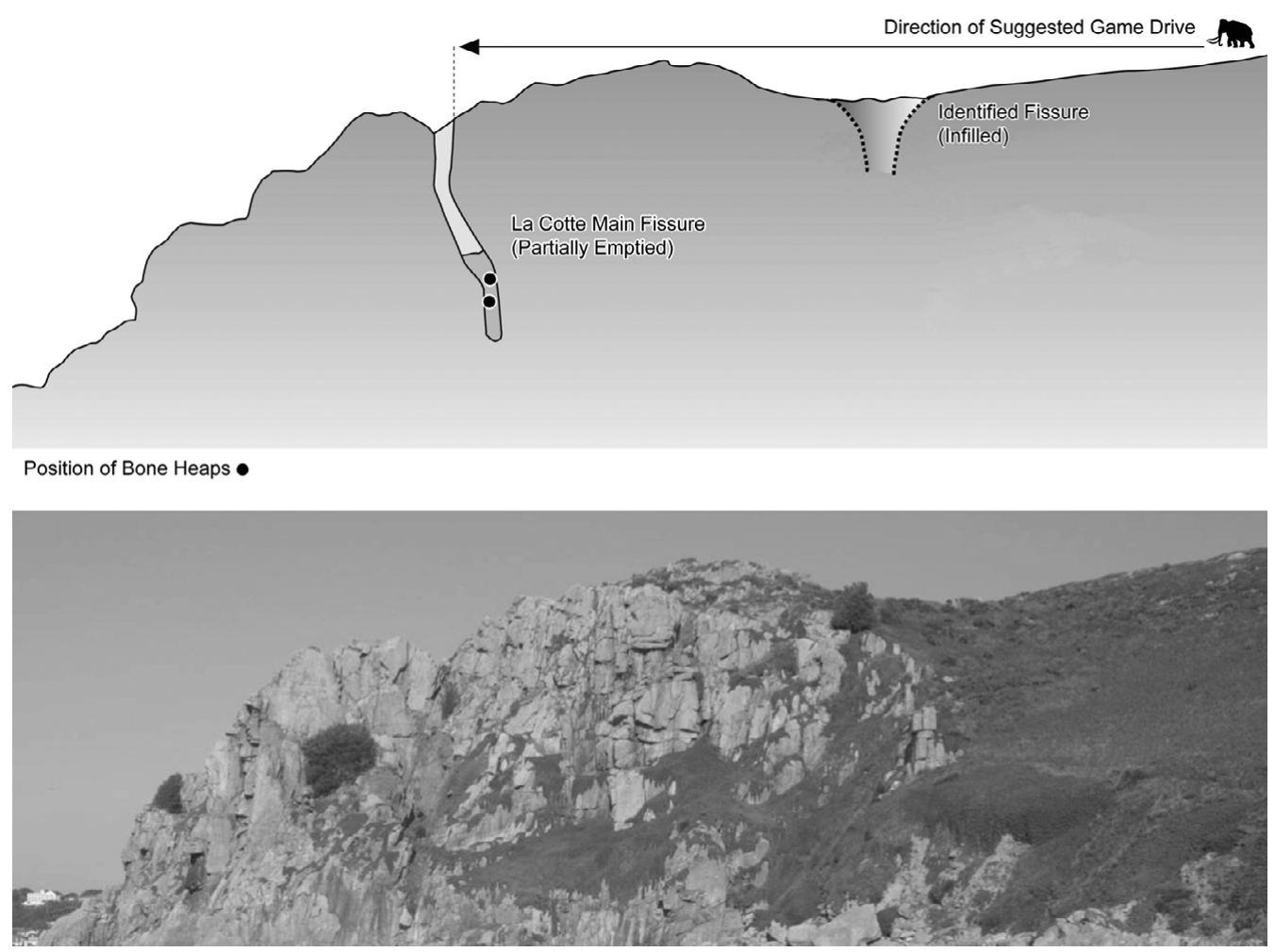

Figure 4. A) Schematic representation of potential in-filled fissure inland of La Cotte; B) view of headland from the south, showing La Cotte and inland fissure (vegetated).

The processed results included a map or bathymetric chart of depths with $0.2 \mathrm{~m}$ vertical resolution and at a lateral bin-resolution of $0.5 \mathrm{~m}$ (Figure 6). Sonar was also used to simultaneously acquire information on seafloor backscatter. Backscatter describes sonar signal strength reflected from the seafloor; hard substrates such as rock produce a stronger reflectivity, and thus backscatter, than soft substrates such as mud. After initial data processing for both bathymetry and backscatter, the data was uploaded to ArcGIS (v10) for integration with terrestrial data (Figure 7).

The survey area extended west to east from Corbier lighthouse to Portelet Bay, and from the intertidal area of St Brelade's Bay south to $4 \mathrm{~km}$ offshore. Greatest depths (over $25 \mathrm{~m}$ ) were recorded in the south and west, with two large rocky ridges extending west-east across the study area. These ridges are heavily dissected by valleys that mirror the granitic coastline, with steep cliffs and $20 \mathrm{~m}$-tall rock pinnacles. Two major east-west valleys separate the ridges (Figure 6).

Another significant area exists at the southernmost margin of the region surveyed; here the seabed drops to below $-20 \mathrm{~m}$, suggesting a line of granite cliffs, forming a drowned terrestrial coastline during times of lowered sea level. Such areas may contain similar caves and fissures to La Cotte, and therefore represent potential sea floor capture points for evidence of past human activity, as well as providing the potential to more accurately reconstruct changing sea level on the southern side of the Channel river.

(C) Antiquity Publications Ltd. 


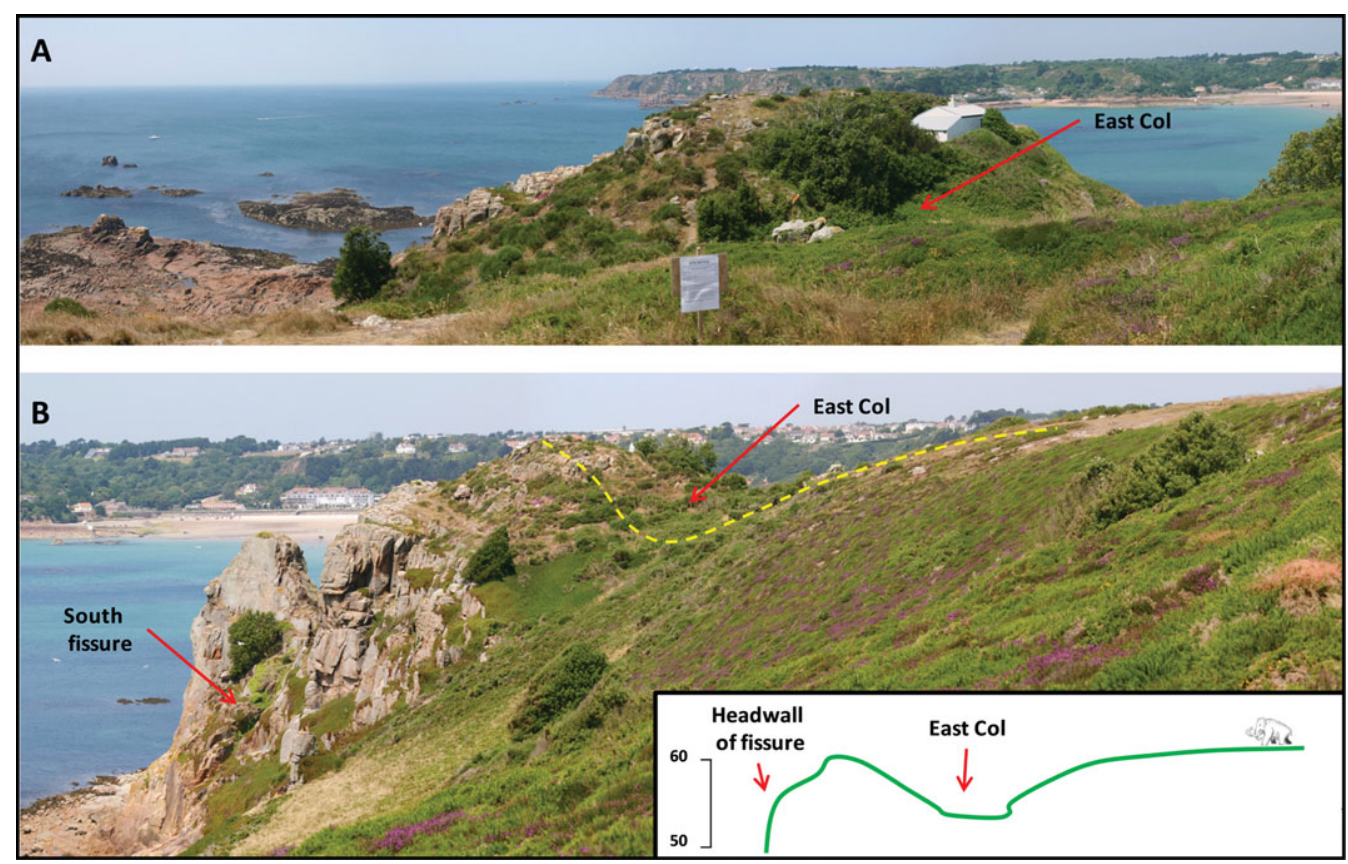

Figure 5. A) View of the approach to the La Cotte fissure from Portelet Common, crossing the steep dip and climb across East Col; B) relative heights of dip and climb to reach the La Cotte headland.

Combining the onshore and offshore data provides a fresh perspective on Neanderthal occupation of the site when sea level was lower. The data showed that rather than sitting at the edge of a rather flat and featureless landscape (the tabula rasa effect of modern sea level), La Cotte was located at the margins of a relatively complex and structure-led granite landscape of bluffs, canyons and valleys. The hard architecture of this landscape had the following features:

1) The west-east trending structure of the geology provided the major potential routes through the now-submerged Pleistocene landscape.

2) Now-submerged granite reefs would have comprised a network of steep-sided valleys controlled largely by joint and fault structures in the granite, giving rise to access patterns reminiscent of gridded street plans (Figure 6).

3) Most importantly, a small valley is mapped running in a northerly direction from one of the major valley systems, directly towards the south-facing entrance of La Cotte (Figure 6). This valley ends in an abrupt line of rising granite bluffs just below the site.

From the detail of this survey we can now determine the view from La Cotte de St Brelade was far from flat and featureless; during times of low sea level, the cave overlooked-indeed, commanded - a view over a highly structured landscape of variable relief. In contrast to the difficult game-drive terrain of the upper plateau, the grid-patterned landscape and dead-end valley offered Neanderthals a landscape in which large mammals could be both effectively controlled and ambushed. 


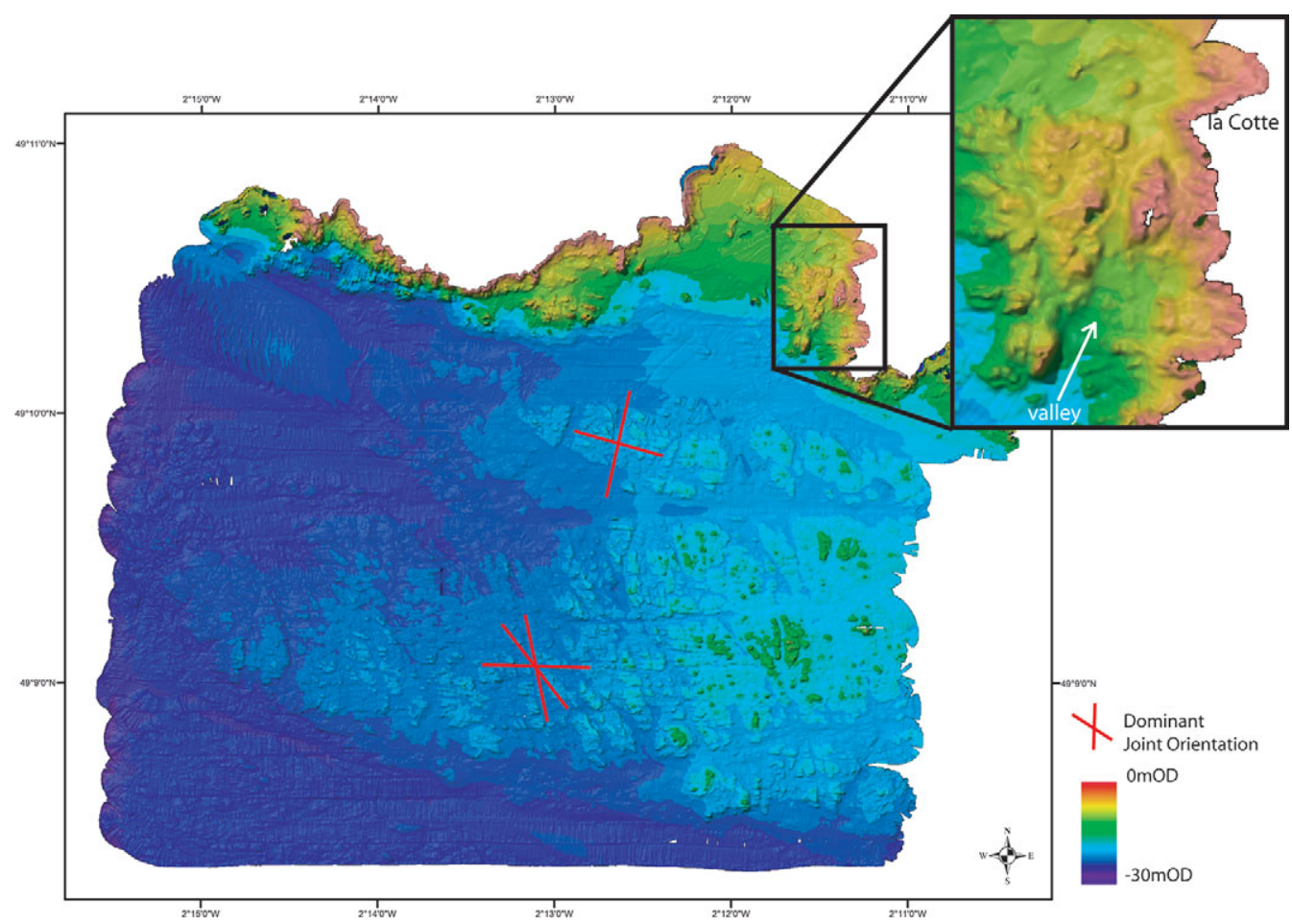

Figure 6. Bathymetric chart of the area surveyed; depths given to $0.2 \mathrm{~m}$ vertical resolution and at a lateral bin-resolution of $0.5 \mathrm{~m}$. Inset shows detail of valley running north up to south entrance to La Cotte fissure system.

\section{Reviewing the mass kill: the archaeological and sedimentary context of the bone heaps}

The new perspective gained from acquiring an appreciation of La Cotte's landscape context developed alongside our reassessment and overview of material from the site. Our close reading of the published monograph (Callow \& Cornford 1986) allowed us to appreciate that the game drive hypothesis was a conclusion grounded soundly on compelling data, but also that it was not the only possible explanation for the bone heaps entertained by Scott, Callow and Cornford (Callow \& Cornford 1986, and chapters therein). We set out to try to understand how the hypothesis could be tested and what aspects of interpretative ambiguity in the original research could be brought into clearer focus. While this preliminary study necessarily concentrated on the bone heaps, we were mindful to develop a 'whole-site' approach, believing that behaviour could only be isolated from natural processes through considering the entire sequence and the site's changing landscape and environmental setting.

\section{Sedimentary context and taphonomy of the bone heaps}

The bone heaps comprise two accumulations of mammoth and woolly rhino preserved within loess (layers 3 and 6). The bone heap of layer 3 overlies a rich occupation level (layer A), sealed by loess, beneath granite slabs spalled from the walls. These slabs underlay a (C) Antiquity Publications Ltd. 


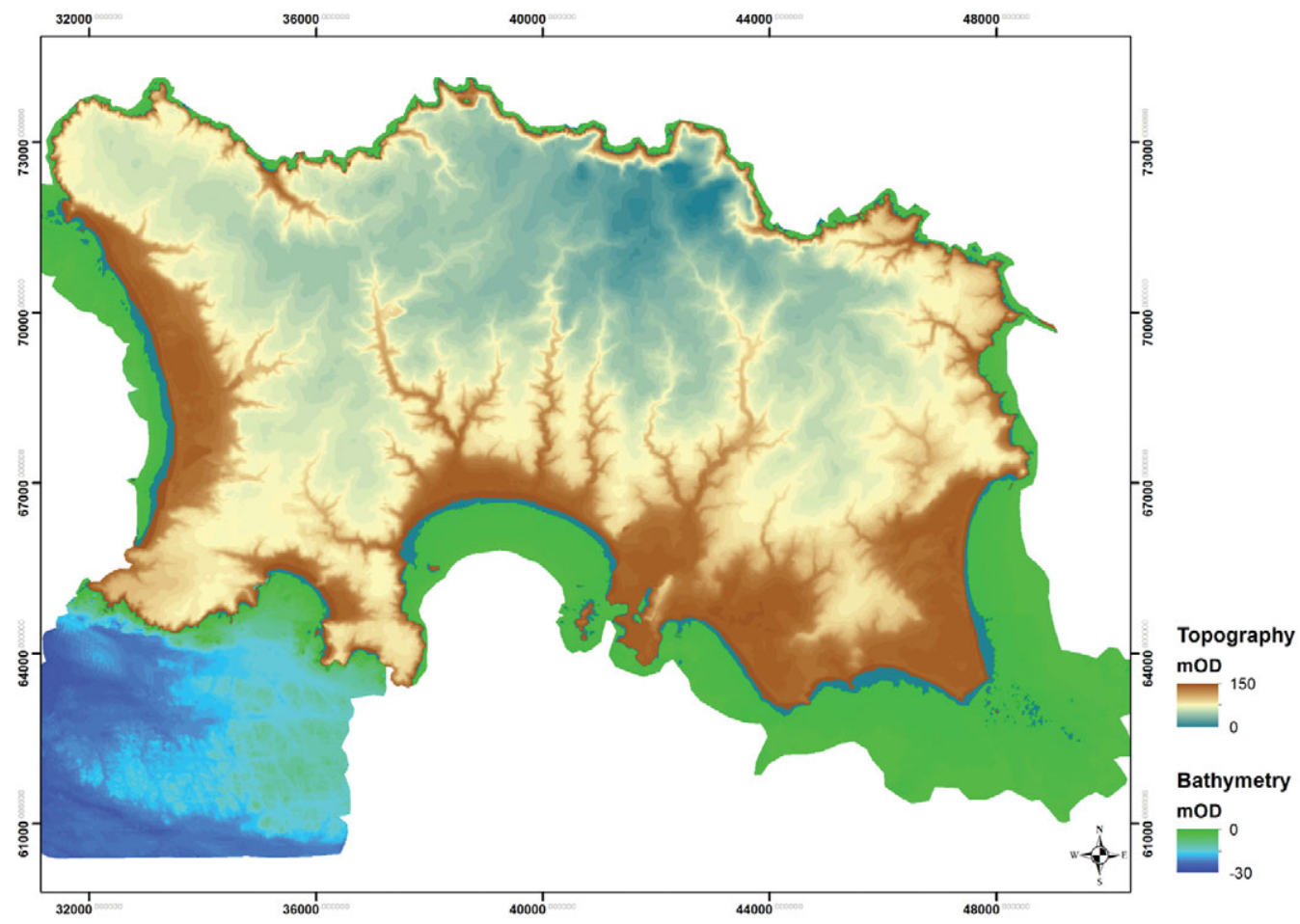

Figure 7. Results of bathymetric survey integrated with terrestrial topographic survey.

second, thinner, yet equally dense occupation (layer 5), in the top of which was embedded the second, upper bone heap sealed by loess (layer 6.1; Callow 1986a: 81; see Figure 8). The discrete depositional nature of the bone heaps is discussed by different contributors to the monograph (Callow \& Cornford 1986).

Scott $(1980,1986 b)$ emphasised contrasts in composition; the bone heaps dominated by mammoth and woolly rhino lacked the more varied fauna of other levels. The layer 3 fauna (the larger bone heap) was distinct from layer A in lacking horse. Although horse was attributed to interface layers in the field (2/3-junction between layers $A$ and 3), none was mixed into the bone heap itself (Scott 1986a: 115). Where overlain by the layer 3 bone heap, layer A was a cemented breccia; mammoth and rhino bones rested on its surface, but did not penetrate into it. The smaller, upper bone heap (mantled by loess 6.1), however, was partly embedded in the underlying occupation horizon (layer 5). This bone heap exhibits some striking features; the bones were stacked against the western wall, with two rhino skulls on top (Scott 1986b: 159). Both bone heaps occupied single planes, bones lying on each other, with some resting on end. One rib is driven into a mammoth skull through the parietal into the occipital (Scott 1980: 144-45). It is difficult to envisage how bones could have accumulated in this way through natural processes.

The striking arrangement of the bone heaps could only be detected during excavation because of the manner in which both were sealed by loess. It seems likely that this burial was swift, as very few of the bones showed any evidence of surface weathering, and some were 


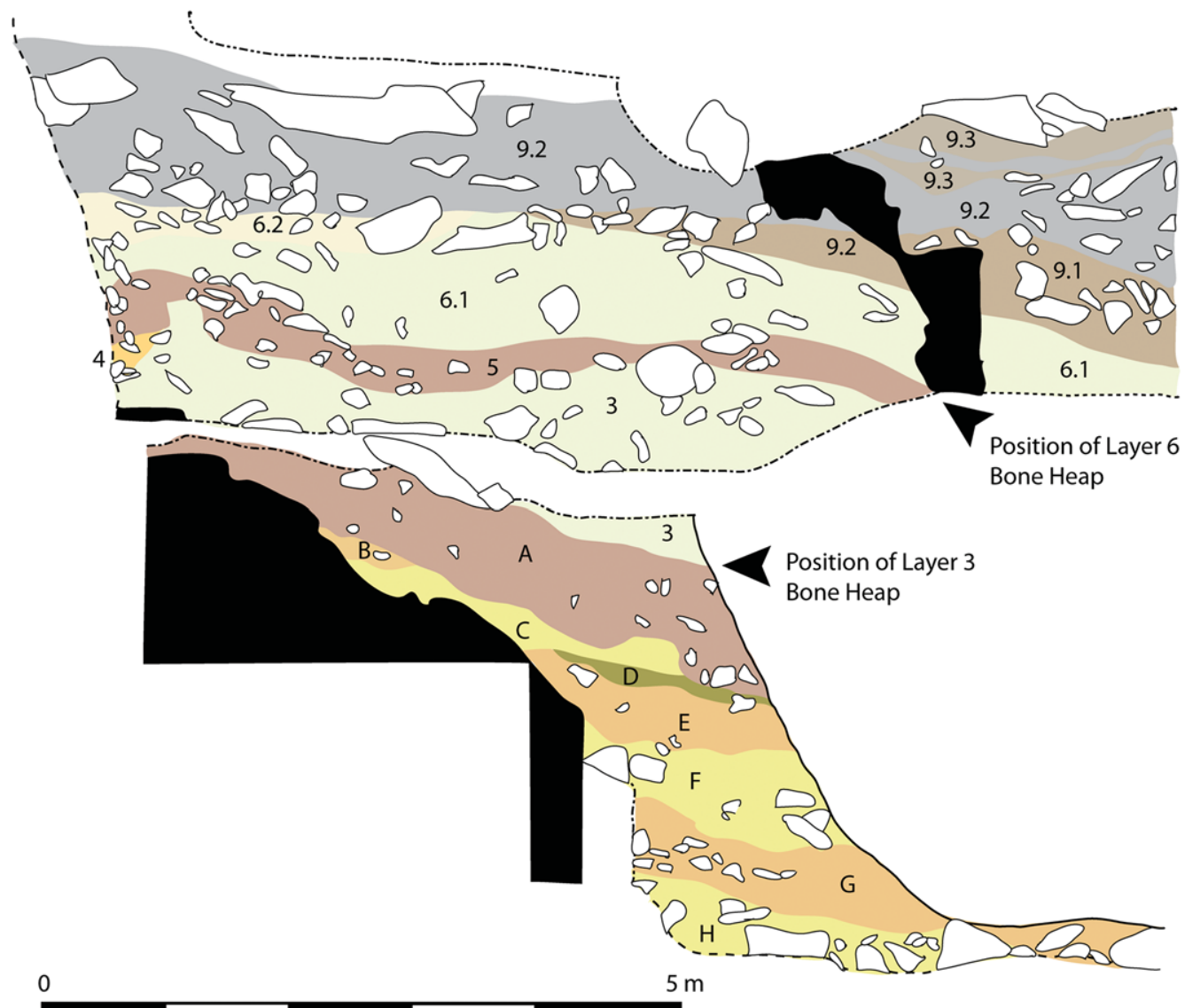

Figure 8. Composite section (west-facing) through the deposits infilling La Cotte de St Brelade, showing the position of the bone heaps (modified from Callow 1986a: 61, fig. 6.6).

recovered in articulation (Scott 1986b: 169-70). There are few artefacts associated directly with the bone heaps, and other occupation debris - such as charcoal and burnt bone-is also scarce. In contrast, the occupation layers which underlie the bone heaps and comprise most of the sequence contain abundant evidence for fire management (charcoal and burnt bone), quantities of crushed and comminuted bone forming bone-rich breccia in a loessic matrix, and abundant lithics (Scott 1986a: 115).

Whilst Scott stressed the unique nature of the bone heaps, Callow emphasised that they formed part of the cyclical loess sedimentation that provided the matrix for the underlying layers (A and 5). He viewed these occupations as ending with the deposition of loess over the bone heaps as conditions cooled (Callow 1986a: 59).

The precise relationship between the bone heaps and underlying occupation deposits requires resolution. One possibility is that their apparent peculiarity may be a preservational accident; they record final occupation before abandonment, and look very different to when the site was more intensively used. The bone breccia of layers $A$ and 5 may once have been carefully arranged, but ongoing occupation resulted in rearrangement, crushing and (C) Antiquity Publications Ltd. 
burning. The site was not reoccupied during the extreme cold of loess deposition, which swiftly sealed and preserved the bone heaps. It is necessary to test whether the behaviours associated with bone heap formation differ from those apparent throughout the rest of the sequence, and especially in the layers they overlie.

\section{Faunal assemblage composition and evidence for human modification}

Reanalysis of the fauna from La Cotte has confirmed many of Scott's original observations (Smith 2012, 2013). Scott (1986b) emphasised clear differences between the faunal material from the bone heaps and that from the rest of the sequence. The bone heaps produced the vast majority of the identifiable bones from the site, together with layer A (directly beneath layer 3; see Table 1). However, the reduced proportion of identifiable species from the rest of the sequence belies the fact that bone was in fact extremely common throughout these deposits. Many fragments were plotted during excavation, but most were too fragile to be recovered, let alone identified (Scott 1986a: 110).

Even allowing for their fortuitous preservation, the faunal assemblages from the bone heaps do exhibit some noteworthy features, beyond their peculiar arrangement. Scott (1980) suggested that relatively large numbers of young and prime-aged mammoth and woolly rhino reflected a living herd structure; solitary, young rhinos are frequently found at the edge of modern elephant groups. On this basis, she suggested that the bone heaps were more likely to be the residues of a mass kill than individual episodes of hunting.

Skeletal element representation of mammoth within the bone heaps is equally curious, as has been reinforced by reanalysis. Layer 3 is dominated by head elements, together with pelvic bones, scapulae and some forelimb elements. In contrast, layer 6 is mostly composed of large, axial post-cranial bones (scapulae and pelves) and hindlimbs (especially femurs; Scott 1986b: 159-60). The carcass portions represented within both bone heaps are large and would have been extremely heavy; such elements are not usually transported away from a kill/butchery site (Scott 1986b: 173). That these heaps exhibit inverse skeletal patterns to one another was taken by Scott to indicate that they represent the remains of butchering fairly complete mammoths, but, as the excavated areas are small, only specific parts of the butchery floors were exposed. Thus, limbs might be processed in one area and heads in another. Further evidence for butchery of mammoth from the bone heaps was identified by Scott and colleagues (Scott 1980; Jones \& Vincent 1986) in the form of cutmarks and other modifications.

The contrast between the fragmented faunal assemblage from the sequence as a whole and the extensive mammoth fauna from the bone heaps does fit the suggestion that the bone heaps only appear unusual because of their position and sedimentary context. Two further lines of evidence support this; firstly, the remains of horse, red deer, bovids and other large mammals from the bone heaps are limited to only the lowermost levels (Scott 1986a: 115), suggesting that they represent residual material from the underlying occupation horizons (layers A and 5). Secondly, almost all the microfauna from La Cotte was recovered from the loess of the bone heaps (especially layer 3; Chaline \& Brochet 1986). Combined with the peculiar arrangement of the bone heaps (stacked, on end, and occupying single planes), this preservation is arguably attributable to the loess that mantles them.

(C) Antiquity Publications Ltd. 


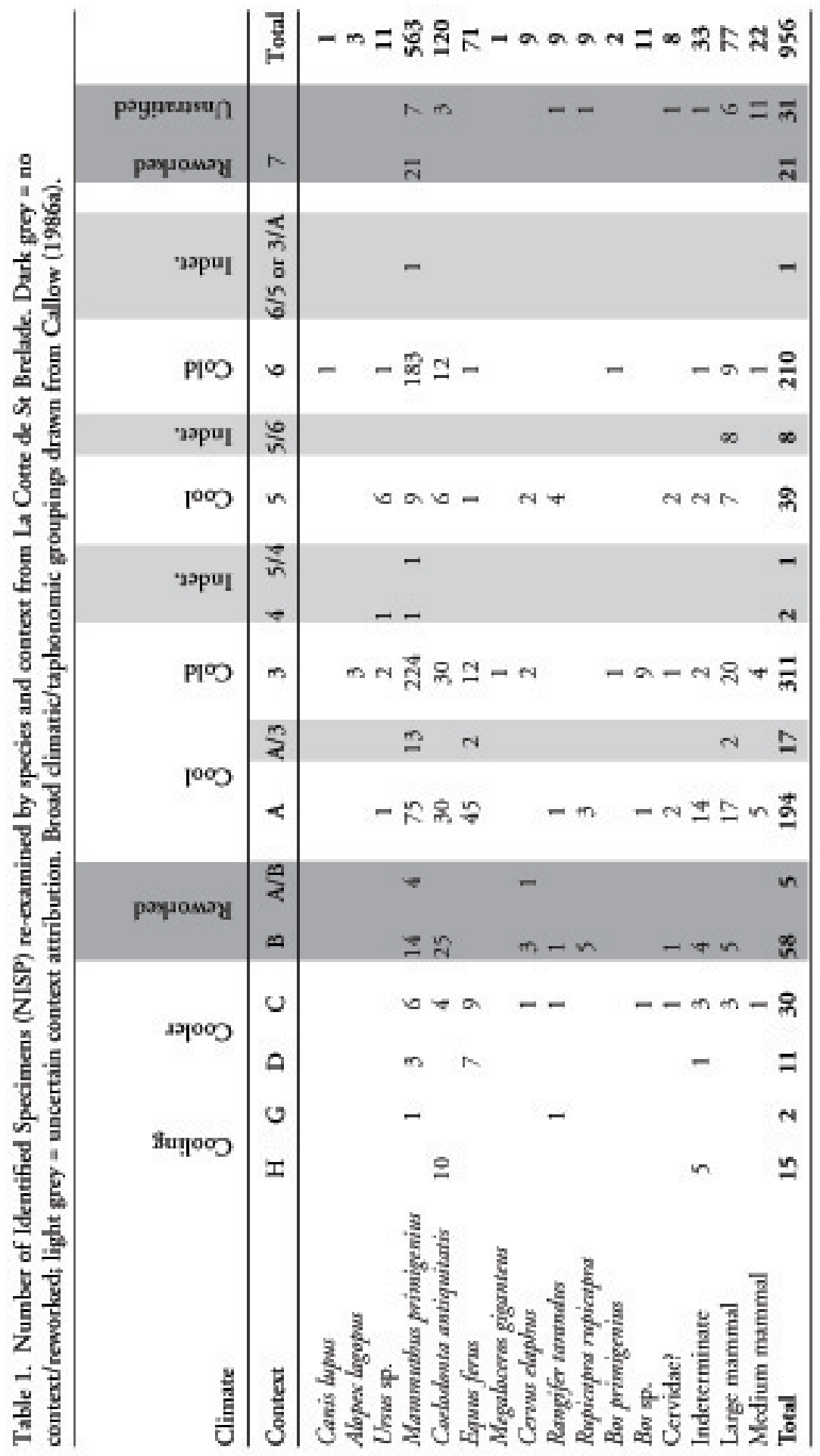

$\odot$ Antiquity Publications Ltd. 
It thus seems possible that the apparently unique composition of the bone heaps might reflect the conditions by which they are preserved. In contrast to the bone heaps, the fauna from the rest of the sequence is fragmented, comprising generally robust pieces, such as teeth. Such elements are more likely to survive ongoing occupation and rearrangement than more fragile bones. The bone heaps, however, seem to represent the residues of the final occupation of the site before substantial loess fall-reflecting the onset of extreme cold conditions. These levels therefore reflect snapshots of site-use at particular points in time, rather than palimpests within which behaviour is obscured by ongoing use. It is this accident of abandonment and preservation which renders the behaviours they reflect visible.

Given the size of the carcass portions represented, Scott (1986b: 173) suggested two scenarios: that the animals must have died either within the fissure itself (having been driven off the cliff), or in the immediate vicinity of the site. Although Scott (1986b) favoured the game drive hypothesis, the import of carcasses from the immediate vicinity was presented as an alternative explanation (Callow 1986b). While it seems clear that Neanderthals were butchering the mammoth remains that make up the bone heaps, determining how they came to be within the ravine system requires the development of a sophisticated analytical programme. We suggest, on the basis of the above assessment, that a wider perspective is required, incorporating taphonomic and behavioural models that take into account the whole sequence at the site, rather than explaining the bone heaps as isolated entities in themselves.

\section{Neanderthal tool use and the bone heaps}

An example of this whole-site approach to La Cotte is our assessment of behavioural evidence from the lithic assemblages. The artefact assemblages from layers 3 and 6 were not analysed as part of the 1986 monograph, being viewed as statistically invalid samples. This was unfortunate, as these were the assemblages directly associated with the bone heaps. If the bone heaps themselves reflect unique behaviours this could be reflected in the stone artefacts accompanying the bones. While few artefacts are firmly assigned to layer 6, some 786 artefacts have been analysed from layer 3 . This assemblage provided a sample of artefacts associated with the lower of the two main bones heaps, within an otherwise sterile loess bed. The underlying layer (A), by contrast, contained a substantial lithic assemblage of 31847 pieces, associated with rich deposits of occupation debris in the form of burnt bone, charcoal and degraded bone-abundant evidence of Neanderthal occupation. Our whole-site approach suggests that comparing the lithics from the two contrasting deposits might throw light on variation in Neanderthal behaviour and, ultimately, the origin of the bone heaps.

Layer 3: within this layer discoidal flaking of small cores dominates, an approach that appears to have been adopted at the tail end of reduction-these cores and products are amongst the smallest from the site. Levallois flaking, which dominates almost all other north-west European MIS 8-6 sites (Scott \& Ashton 2011) is poorly represented, frequently on local, non-flint raw material. Recycling of retouched tools, and unretouched edges, is indicated by numerous resharpening flakes (72; 10.5 per cent of sample) struck down flake edges. Often these reflect repeated resharpening, representing an elegant, economical way of conserving tractable raw material. 
Layer A: cores and resultant flakes are also small (Hutcheson \& Callow 1986: 249); similarly, longitudinal resharpening flakes and discoidal cores are common. Overall, the technological strategies employed during the formation of both layers are similar-with a notable exception; handaxes are recorded as present in layer A. In fact, most of the bifaces from the site come from this level (70 bifacial pieces; Callow 1986b: 311). Initial re-examination of the layer A material during archive re-organisation, however, did not show up many handaxes; many bifacial pieces actually appear to be core fragments (personal observation by present author BS, May 2012).

Initial assessment of the previously unanalysed layer 3 stone artefacts suggests behavioural continuity between the main occupation layer $\mathrm{A}$ and the layer 3 bone heap. It is a signature that lends weight to the possibility that both should be considered as one single assemblage, with layer 3 effectively being a sterile loess deposit which sealed the underlying occupation unit, including artefacts derived from below, and preserving faunal material at the very end of the deposition of layer $\mathrm{A}$ in a spectacular fashion.

This pattern seems plausible in isolation but when considered in the context of the whole site, it becomes more compelling. A rhythm between occupation and apparent bone heap accumulations is also witnessed in the transition from occupation layer 5 into bone heap 6 . Sedimentation at the site reflects a single, variable system of climate-driven accumulation and Neanderthal occupation.

\section{(Re)viewing La Cotte de St Brelade: towards a heterogeneous account of Neanderthal behaviour}

Since publication of the Callow and Cornford monograph, views of Neanderthal behaviour have shifted profoundly. Anglophone literature of the 1980s cast Neanderthals as reactive animals and peripheral scavengers (e.g. Binford 1985), subsisting on ice-ravaged carcasses, equipped only with snow probes (cf. Gamble 1987). The game-drive hypothesis offered a significant challenge to such models, implying not only primary access to carcasses, but also the social organisation necessary to drive mammoth herds and calmly butcher them. Throughout the 1990s, it became accepted that specialised hunting was a developed Neanderthal adaptation; they did not simply take animals in proportion to their availability, but deliberately targeted particular species at particular times—and indeed, scavenged at others.

Hunting behaviour appears to have intensified from MIS 7 onwards in north-western Europe; cutmarks became increasingly common, potentially reflecting changing processing practices (Gamble 1999: 237). Numbers of species within faunal assemblages decrease (usually 2-3, with more monospecific assemblages; Gaudzinski \& Turner 1996; PatouMathis 2000). These changes are arguably linked to increasingly logistical approaches; for example, the deliberate targeting of places for particular activities, such as raw material procurement or the hunting of specific prey.

Examples of monospecific prey selection become widely apparent during the later Middle Palaeolithic (at least MIS 5d onwards), often associated with strategic hunting at specific points in the landscape (White $e t$ al. in prep; see also Speth 2012). Monospecific faunal accumulations (often bovids; Gaudzinski 1996) are known from situations where the landscape may have formed a topographic trap; bison trapped against a low cliff (C) Antiquity Publications Ltd. 
at Mauran (MIS 5/4; Farizy et al. 1994), bovids at Coudoulous (MIS 6; Brugal et al. 1998) and aurochs at La Borde (MIS 5e; Jaubert et al. 1990). At Starosele in the western Crimea, equids were apparently driven into a box canyon and ambushed from behind a bend in the cliff (MIS 3; Burke 2000). Evidence of reindeer-hunting at SalzgitterLebenstedt suggests further specialisation — targeting prime-aged adult male reindeer, using the point where a tunnel valley narrows as an ambush location (MIS 5e; Gaudzinski \& Roebroeks 2000). These advances, on evolutionary timescales, should not be expected to occur in isolation. It should be possible to identify changes in settlement and logistical, technological and social aspects of Neanderthal life that developed alongside subsistence behaviour.

Our new view of La Cotte rests on its long record of occupation spanning 238-40 k BP; a period of profound environmental change in which we should expect variable behavioural responses from Neanderthal groups. The constant factor is the site itself, affording shelter and commanding views over a structured, dissected landscape. Our interpretation of the lithic and faunal assemblages suggest that the majority of material from La Cotte (such as the dense accumulations of material from layers $A$ and 5), relates to long-term, but not necessarily continuous, occupation of the site by Neanderthals. At times the site could simply have been used strategically, commanding an excellent hunting locale, and other times it appears to have been abandoned altogether.

More detailed examination of raw material transport and use-immediate raw material was rarely used - and carnivore activity may help tease out the finer details of the occupation history. With a closer analysis of changing behaviour and climatic signatures, such as the rhythm of loess deposition and abandonment, even finer resolution might be achieved in behavioural responses of the Neanderthal hunters to climate change. For example, the decline in horse noted by Scott (1986b) between layer A and the layer 3 bone heap, where it is replaced by mammoth, might reflect changing species concomitant with cooling. The suggestion is that Neanderthals continued to use the site to acquire game, but the targeted species varied in response to changing climate.

To conclude, La Cotte de St Brelade provides a focal point from which we can infer behavioural changes amongst the Neanderthals of the southern Channel river plain; however, past focus on the bone heaps has blinded us to its wider significance. The bone heaps simply represent two features within an extensive sequence of Neanderthal occupation; whether they represent two discrete behavioural episodes is a matter of interpretation. Even if accepted as a mass kill signature, the Neanderthal achievement at La Cotte was not driving mammoths over a headland, it was meeting the adaptive challenges of extreme climate change while maintaining a long-term, if punctuated, presence in the region. Given the vast span of time and environmental variation involved, no single hunting strategy or behavioural model can be expected to explain the archaeological signatures at the site. The only constant is the structure of the site itself; a sheltered ravine and cave system at the interface between the plains of the St Malo Gulf and the Jersey Plateau, commanding a structured landscape of gullies and a single, dead-end valley. The combination of long-term settlement signatures (including fire use and lithic transport) combined with the strategic use of landscape might represent an example of niche construction, allowing effective exploitation of challenging, dynamic environments. 


\section{Acknowledgements}

Grateful thanks are extended to Jersey Heritage, the Société Jersiaise, the States of Jersey Department of Planning and Environment, and Jersey Digimap; to the NERC, AHOB 3 and CAHO for excavation funding. BS's contribution forms part of the AHOB 3 and 'Pathways to Ancient Britain' projects, funded by the Leverhulme Trust and the Calleva Foundation. GS was funded by the QRA. We also thank Lucy Bolton, James Cole, Sam Griffiths, Andy Needham, Dave Underhill, Karen Ruebens and Rebecca Wragg-Sykes.

\section{References}

Bates, M.R., N. Nayling, R. Bates, S. Dawson, D. Huws \& C. WiCKHAM-JONES. 2012. A multi-disciplinary approach to the archaeological investigation of a bedrock-dominated shallow-marine landscape: an example from the Bay of Firth, Orkney, UK. International Journal of Nautical Archaeology 42: 24-43. http://dx.doi.org/ 10.1111/j.1095-9270.2012.00360

BINFORD, L. 1985. Human ancestors: changing views of their behaviour. Journal of Anthropological Archaeology 4: 292-327.

Boismier, W.A., C. GAMble \& F. CoWArd (ed.). 2012. Neanderthals among mammoths: excavations at Lynford Quarry, Norfolk, UK. London: English Heritage.

Brugal, J.-Ph., S. Costamagno, J. Jaubert \& V. Mourre. 1998. Les gisements paléolithiques de Coudoulous (Tour-de-Faure, Lot, France), in F. Facchini, A. Palma di Cesnola, M. Piperno \& C. Peretto (ed.) Actes du XIII Congrès de l'UISPP, Forli, vol. 2: 141-45. Forlì: UISPP.

BurKe, A. 2000. The view from Starosele: faunal exploitation at a Middle Palaeolithic site in western Crimea. International Journal of Osteoarchaeology 10: 325-55. http://dx.doi.org/ 10.1002/1099-1212 (200009/10) 10:5<325::AID-OA556>3.0.CO;2-T

CALlOW, P. 1986a. The stratigraphic sequence: description and problems, in P. Callow \& J.M. Cornford (ed.) La Cotte de St Brelade 1961-1978. Excavations by C.B.M. McBurney: 55-73. Norwich: Geo.

- 1986b. The flint tools, in P. Callow \& J.M. Cornford (ed.) La Cotte de St Brelade 1961-1978. Excavations by C.B.M. McBurney: 251-314. Norwich: Geo.

- 1986c. Appendix C. La Cotte à la Chèvre, in P. Callow \& J.M. Cornford (ed.) La Cotte de St Brelade 1961-1978. Excavations by C.B.M. McBurney: 409-11. Norwich: Geo.

Callow, P. \& J.M. Cornford (ed.). 1986. La Cotte de St Brelade 1961-1978. Excavations by C.B.M. McBurney. Norwich: Geo.

Chaline, J. \& G. Brochet. 1986. The rodent fauna, in P. Callow \& J.M. Cornford (ed.) La Cotte de St Brelade 1961-1978. Excavations by C.B M. McBurney: 139-44. Norwich: Geo.

(C) Antiquity Publications Ltd.

CHASE, P. 1986. Hunters of Combe Grenal: approaches to Middle Paleolithic subsistence in Europe (British Archaeological Reports international series 286). Oxford: British Archaeological Reports.

Demay, L., S. Péan \& M. Patou-Mathis. 2012. Mammoths used as food and building resources by Neanderthals: zooarchaeological study applied to layer 4, Molodova I (Ukraine). Quaternary International 276-77: 212-26. http://dx.doi.org/ 10.1016/j.quaint.2011.11.019

FARIZY, C., F. DAVID \& J. JAUBERT. 1994. Hommes et bisons du Paléolithique Moyen à Mauran (Haute-Garonne). Paris: CNRS.

Gamble, C. 1987. Man the shoveller: alternative models for Middle Pleistocene colonisation and occupation in northern latitudes, in O. Soffer (ed.) The Pleistocene Old World: regional perspectives: 81-98. New York: Plenum.

- 1999. The Palaeolithic societies of Europe. Cambridge: Cambridge University Press.

GAUDZINSKI, S. 1996. On bovid assemblages and their consequences for the knowledge of subsistence patterns in the Middle Palaeolithic. Proceedings of the Prehistoric Society 62: 19-39.

Gaudzinski, S. \& W. Roebroeks. 2000. Adults only: reindeer hunting at the Middle Palaeolithic site Salzgitter Lebenstedt, northern Germany. Journal of Human Evolution 38: 497-521. http://dx.doi.org/ 10.1006/jhev.1999.0359

GaUdzinski, S. \& E. TURner. 1996. The role of early humans in the accumulation of European Lower and Middle Palaeolithic bone assemblages. Current Anthropology 37: 153-56.

GENESTE, J.-M. 1989. Economie des resources lithiques dans le Mousterien du sud-ouest France, in L. Freeman \& M. Patou-Mathis (ed.) L'Homme de Néandertal. Volume 6: la subsistence (ERAUL 33): 75-97. Liège: Université de Liège.

Hutcheson, J.C.C. \& P. CALlow. 1986. The flint debitage and cores, in P. Callow \& J.M. Cornford (ed.) La Cotte de St Brelade 1961-1978. Excavations by C.B.M. McBurney: 231-51. Norwich: Geo.

Jaubert, J., M. LORblanchet, A. TurQ \& J. Brugal. 1990. Les chasseurs d'aurochs de La Borde: un site du Paléolithique Moyen (Livernon, Lot). Paris: Maison des sciences de l'homme. 
JONES, P.R. \& A.S. VINCENT. 1986. A study of bone surfaces from La Cotte de St Brelade, in P. Callow \& J.M. Cornford (ed.) La Cotte de St Brelade 1961-1978. Excavations by C.B.M. McBurney: 185-93. Norwich: Geo.

de Knegt, H.J., F. van Langevelde, A.K. Skidmore, A. Delsink, R. Slotow, S. Henley, G. Bucini, W.F. de Boer, M.B. Coughenour, C.C. Grant, I.M.A. HeITKÖNIG, M. HENLEY, N.M. KNOX, E.M. Kohi, E. Mwakiwa, B.R. Page, M. Peel, Y. Pretorius, S.E. VAN WiEREN \& H.H.T. Prins. 2010. The spatial scaling of habitat selection by African elephants. Journal of Animal Ecology 80: 270-81. http://dx.doi.org/10.1111/j.13652656.2010.01764.x

Patou-Mathis, M. 2000. Neanderthal subsistence behaviours in Europe. International Journal of Osteoarchaeology 10: 379-95. http://dx.doi.org/ 10.1002/1099-1212(200009/10)10:5<379::AIDOA $558>3.0 . \mathrm{CO} ; 2-4$

Pope, M., M. Bates, J. Cole, C. Conneller, K. Ruebens, B. Scott, A. Shaw, G. Smith, D. UNDERHILL \& R. WRAGG-SYKES. 2012. Quaternary environments and archaeology of Jersey: a new multidisciplinary project looking at the early prehistoric occupation of the English Channel Region, in K. Ruebens, I. Romanowska \& R. Bynoe (ed.) Unravelling the Palaeolithic: ten years of research at the Centre for the Archaeology of Human Origins (CAHO, University of Southampton): 27-39. Oxford: Archaeopress.

ScOTT, K. 1980. Two hunting episodes of Middle Palaeolithic age at La Cotte de Saint Brelade, Jersey. World Archaeology 12: 137-52.

- 1986a. The large mammal fauna, in P. Callow \& J.M. Cornford (ed.) La Cotte de St Brelade 1961-1978. Excavations by C.B.M. McBurney: 109-39. Norwich: Geo.
- 1986b. The bone assemblages from layers 3 and 6 , in P. Callow \& J.M. Cornford (ed.) La Cotte de St Brelade 1961-1978. Excavations by C.B.M. McBurney: 159-85. Norwich: Geo.

ScotT, B. \& N. Ashton. 2011. The Early Middle Palaeolithic: the European context, in N.M. Ashton, S.G. Lewis \& C.B. Stringer (ed.) The ancient human occupation of Britain. Amsterdam: Elsevier.

Smith, G.M. 2012. Did Neanderthals hunt mammoths on Jersey? A reconsideration of the 'bone heaps' from La Cotte de St Brelade. Quaternary Newsletter 128: 49-53.

- 2013. La Cotte de St Brelade, Jersey: re-evaluating Neanderthal subsistence behaviour and landscape use [abstract only]. Proceedings of the European Society for the Study of Human Evolution 2: 211.

SPETH, J.D. 2012. Thoughts about hunting: some things we know and some things we don't know. Quaternary International 297: 176-85. http://dx.doi.org/10.1016/j.quaint.2012.12.005

STINER, M.C. 1994. Honor among thieves: a zooarchaeological study of Neandertal ecology. Princeton (NJ): Princeton University Press.

Wall, J., J. Douglas-Hamilton \& F. Vollrath. 2006. Elephants avoid costly mountaineering. Current Biology 16: R527-R529.

White, M., P. PettitT \& P. Rowley-Conwy. In preparation. The killing fields: tales of Neanderthal hunting in Middle Palaeolithic Europe.

Zeuner, F. 1946. Cervus elephus jerseyensis and other fauna in the $25 \mathrm{ft}$ beach of Belle Hogue Cave, Jersey, Channel Islands. Annual Bulletin of the Société Jersiaise 14: 238-54.

Received: 21 March 2013; Accepted: 6 June 2013; Revised: 28 October 2013

(C) Antiquity Publications Ltd. 